\title{
THE EFFECT OF LEADERSHIP STYLE AND COMPETENCY TOWARDS EMPLOYEES' WORK SATISFACTION AND PERFORMANCE AT GOVERNOR OFFICE OF SOUTH SULAWESI PROVINCE
}

\author{
Zulkifli hardi , Nurdjannah Hamid ${ }^{2}$, Muh. Yunus Amar, ${ }^{3}$ Amiruddin Amrullah ${ }^{4}$ \\ ${ }^{1}$ Master of Management, Faculty of Economic and Business, Hasanuddin University \\ (email: hardi.zulkifli@gmail.com) \\ ${ }^{2}$ Management Department, Faculty of Economic and Business, Hasanuddin University \\ (email:nununghamid17@gmail.com) \\ ${ }^{3}$ Management Department, Faculty of Economic and Business, Hasanuddin University \\ (email:myunmar@gmail.com ) \\ ${ }^{4}$ Management Department, Faculty of Economic and Business, Hasanuddin University \\ (email: a.amiruddin@fe.unhas.ac.id)
}

\begin{abstract}
The article is offering an investigation on leadership style and competency as an important aspect in building a relationship between superiors and subordinates, which is expected to improve job satisfaction and create a good performance. The study aims to investigate the direct and indirect effect of democratized, delegated leadership and competency towards work satisfaction; the data were collected by distributing questionnaire. The research method used is path analysis with employing a sample of 60 respondents at south Sulawesi governor's Office. The study indicates that the democratized and delegated leadership as well as competency have a direct effect on work satisfaction. It also shows that work satisfaction has a direct effect on the employees' performance, and work satisfaction.
\end{abstract}

Keywords: Democratized and delegated leadership, work satisfaction, and performance

\section{INTRODUCTION}

The role of leadership will be important and necessary to harmonize the various needs and also to create a more conducive working situation. Besides, it can encourage employees to behave in accordance with organizational goals that have been established. Based on the observations, the existing leadership style in the Office of the Governor of South Sulawesi Province Sub Division of Unity Nations and politics tend to embrace democratic and delegated leadership style. This can be observed from the way leaders engage subordinates jointly in carrying out the vision, mission, and strategy set by the organization.

The situational leadership according to Hersey and Blanchard (1969) is based on the interconnected number of instructions and direction given by the leadership, 
the amount of emotional socio-support provided by the leadership and the level of preparedness or maturity of followers indicated in the performance of specific tasks, functions or objectives (Thoha, 2001). The ability of subordinates in carrying out their duties cannot be separated from the competence they have.

Competence is an aspect of one's ability that includes knowledge, skills, attitudes, values or personal characteristics that enable employees to achieve success in completing their work through achievement of results or success in completing tasks (Noe, 2004). Satisfaction or job dissatisfaction caused by compensation or reward from superiors assessed according to some employees who work at the office or organization. Giving a job to a specific person with a different background will be able to trigger job dissatisfaction within the working environment. Performance is the result or level of success of a person as a whole during a certain period in carrying out the task compared with the standard results of work, targets or targets or criteria are determined in advance and have been mutually agreed.

Referring to the above statement, the two leadership styles - democratic and delegated leadership - are used by employees of Provincial Office of South Sulawesi Sub Division of Political Unity and politics, where this style of leadership has long been adopted by policymakers. Future organizational development is directed at the level of organizational performance improvement so that ultimately in line with the vision and mission of the organization.

In addition, based on field observations indicate that there are several problems that arise in this agency, among them are leaders often entrust one job only to some people who are considered capable without seeing the main tasks and functions of each field. Some employees are even more unemployed than completing their work. During working hours, there are still some uncooperative employees who do activities that are not related to the main job, there are still some employees who are late to come to work or leave the office prematurely. This can degrade performance in the agency.

Some research results on democratic leadership, delegated leadership and competence show leadership, competence, and compensation very significantly affect employee performance (Widyatmini, 2008). The results of research conducted in local office at Maros Regency in Indonesia indicate that there is a positive and significant relationship between leadership style and motivation to employee performance (Bakrie, 2002). 
Based on the above exposure, this study aims to determine the effect of democratic leadership variables, delegated leadership and competence on performance through job satisfaction at the Office of the Governor of South Sulawesi Province of Indonesia.

\section{Human Resource Management}

The term human resource refers to the people within the organization. Managers and human resources activities are part of the work. They seek to facilitate the contributions proposed by people to achieve organizational goals. The significance of human resource efforts is due to the fact that human beings are always an element in every organization. They set goals and find innovation to achieve the goals and goals of the organization. According to Veithzal (2010) human resources management is one of the areas of general management aspects of planning, organizing, implementation and control is a process in the function/field of production, marketing, financial and personnel, human resources is a collection of knowledge about how it should manage human Resources.

\section{Leadership}

Leadership is a narrower concept of management, a manager in a formal organization responsible and trusted with functions such as planning, organizing, and controlling. However, leaders in informal groups are not always normal managers who perform managerial functions required by their organizations. Consequently, leaders are not always a manager.

In the research that wanted to do the researcher focuses on 2 types of leadership that is type democratic and delegated leadership:

\section{A. The style of Democratic Leadership}

Democracy is etymologically derived from the word "demos" which means the people or the inhabitants of a place, and "create" which means power or sovereignty. So, "demos-creating" or democracy is the state of the country wherein the system of government, sovereignty in the people, the supreme authority is in the decisions with the people (Syafie, 2001).

\section{B. Delegated Leadership Style}

According to Murai (2004), the free-rein leadership style (delegation) is the transfer of authority (responsibility) from the leader to the subordinate within an organization in the hope that the task can be accounted for, and resolved on time, and not against the objectives to be achieved. Salusu (2006) argues that the style of 
delegated leadership is a force that encourages the ability of staff to take the initiative. Less interaction and control by the leader so that this style can only work if the staff shows the level of competence and confidence will pursue the goals and objectives of the organization. Permadi (2006), who said that in the style of leadership of delegated type found the values of power transfer or the value of a very high trust from a boss to a subordinate. In addition, the sincere value of a superior is so strong that the subordinate can make the decision responsibly, despite his manager's progress.

\section{Competence}

The terms competencies, 'competence' and 'competent' in Indonesian are translated as competence, competence, and empowerment which refers to the state of a quality capable and appropriate. The English dictionary describes the word 'competence' as appropriate, adequate, or appropriate. The definition of workplace competence refers to the notion of a person's compatibility with his work. But in the job's work, competency has two different meanings, depending on the organizational reference frame.

Competence refers to the underlying characteristics of behaviors that describe motives, personal characteristics (characteristics), self-concept, values, knowledge or skills that a person who performs excels at work. Wibowo (2007) states that competence is an ability to perform or perform a work based on skills and knowledge and supported by the work attitude demanded by the work.

\section{Job satisfaction}

Job satisfaction is an overall effective evaluation of the employee's work resulting from the comparison or actual outcome with the desired people. Job satisfaction is a pleasant emotional state and resulting from the perception of one's job as the fulfillment of one's important work values.

Satisfaction theory bases its approach on the factors of individual needs and satisfaction that cause it to act and behave in a certain way. This theory focuses on the factors within the person who encourage one's work spirit. The thing that motivates one's work morale is to meet the needs and satisfaction both material and non-material obtained as a reward or compensation for services it provides to the company. 


\section{Employee Performance}

Etymologically, performance comes from the word performance. Performance is derived from a word to perform that has several entries, i.e. (1) doing, (2) fulfilling or executing a, (3) carrying out a responsibility, (4) doing something expected by someone. From the input can be interpreted, the performance is to perform an activity and refine the work in accordance with its responsibilities so as to achieve the results as expected.

Murphy and Cleveland (1995) say that performance is a quality of taskoriented or job-oriented behavior. Ndraha (1997) says that performance is a manifestation of the popular relationship between society and government. Widodo (2006) said that the performance is to perform an activity and refine it in accordance with its responsibilities with the expected results.

\section{RESEARCH METHODS}

\section{A. Location and Research Design}

The research is located at the Governor Office of South Sulawesi Province Indonesia. In this study, the authors use quantitative methods. The quantitative research method is very good used to examine the population or a particular sample, sampling techniques are generally done randomly, data collection using research instruments, data analysis is quantitative/statistical with the aim to test the hypothesis that has been set.

\section{B. Population and Sample}

This study selected the target population in the Office of the Governor of South Sulawesi Province Indonesia Nation Unity and Politics. In this research, sampling using saturated sample technique (census). The population of this study is all employees of the Office of the Governor of South Sulawesi Province Sub Division Unity Nation totaling 60 people. Considering that the number is relatively small and easy to reach by researchers.

\section{Method of collecting data}

We collect and obtain the necessary data in conducting the research and discussion through questionnaires. Questionnaire in the form of a questionnaire is a technique of data collection conducted through the provision of questions - questions in writing to the respondent. Likert scale is used to measure the attitudes of respondents to each question or statement. Then, literature study is a data collection 
technique that is done by reading and recording various references such as books, journals, magazines, articles, and others related to the research being done.

\section{Data analysis}

Validity test is used to measure the validity or validity of a questionnaire. A questionnaire is said to be valid if the question on the questionnaire is able to reveal something to be measured by the questionnaire. Test the validity of data in this study is done with technical analysis of items, namely by correlating the score of each item question with the total score for each variable. Correlation technique used in performing validation test is Pearson Product Moment. Data reliability is the extent to which data categorization is consistent if performed by other researchers or by the same researcher in different events (Siregar, 2014). A measuring device is said to be reliable when the tool in measuring a symptom at different times always shows the same result. Reliability test in this research is done by using the Alpha method.

The criterion used to declare a research instrument is said to be reliable if it gives Cronbach Alpha $(\alpha)$ value greater than 0.60 . To simplify the calculation process, then used computer aids with statistical application software.

Path analysis is used to find an explanation of patterns of relationships among variables studied based on theoretical considerations and empirical studies that have been done before and then displayed in the form of drawing (path diagram) as a tool to help to conceptualize complex problems. Path analysis is a method used to see the direct and indirect consequences of the hypothesized variable as the cause of the variables imposed as a result. Variables in this path analysis are exogenous variables as causal and endogenous variables as a result variable. The path coefficient calculation uses Statistic software through partial regression analysis where the path coefficient is standardized coefficients beta for its direct effect, whereas the indirect effect is the multiplication of path coefficients of the path through each equation and the total effect is the sum of the effects directly with all indirect influences.

\section{Results of Analysis and Discussion}

The of democratic leadership variable on Job Satisfaction variable has direct influence; it has a positive and significant relationship between democratic leadership and Job Satisfaction or in other words increase in variable X1 will increase Job Satisfaction (Y1). Delegated leadership variable on Job Satisfaction variable has direct influence; the relationship of delegated leadership has a 
significant positive effect on Job Satisfaction, in other words, increase in variable X2 will increase Job Satisfaction. The direct influence of Competence variable on Job Satisfaction variable can be seen from the standardized coefficient of 0.327 ; leadership relationship Positive Competence significant to Job Satisfaction or in other words increase in variable X3 will increase Job Satisfaction. The direct influence of democratic leadership variable on Employee Performance variable can be seen from the standardized coefficient of 0.402; Positive democratic leadership relationship significant to Employee Performance or in other words increase in variable X1 will improve Employee Performance. The direct effect of Delegated Leadership variable on Employee Performance variable can be seen from the standardized coefficient of. -0.329; the relationship of delegated leadership negatively affect Employee Performance, in other words, increase in variable X2 will decrease Employee Performance. The direct influence of Competence variable to Employee Performance variable can be seen from standardized coefficient at 0.639; Relationship Competence positively significant to Employee Performance or in other words increase in variable X3 will improve Employee Performance. The direct influence of Job Satisfaction variable on Employee Performance variable can be seen from standardized coefficient is 1.062; Relationship Satisfaction Positive significant to Employee Performance or in other words increase in variable $\mathrm{Y} 1$ will improve Employee Performance.

The results showed that Democratic Leadership on Job Satisfaction has a direct and positive significant effect. Therefore, at the Office of the Governor of South Sulawesi Province Sub Section of National Unity and Politics when using the style of Democratic Leadership then the Employee Satisfaction will increase. Conversely, if the Office of the Governor of South Sulawesi Province Sub Section of National Unity and Politics using a style of leadership that is not democratic, then automatically Job Satisfaction will decrease. Similarly, Sedarmayanti (2006), who writes about human approaches, educational ways of acting, is not a weakness possessed by a democratic leader, but as one source of leader, power possessed by a democratic leader. It is said to be a source of strength because with such an attitude will be a respected and respected leader, not a feared leader.

Furthermore, the results of Delegated Leadership study on Job Satisfaction have direct and positive significant effect. If the Office of the Governor of South Sulawesi Province Sub Division of National Unity and Politics using the style of 
Delegated Leadership then Employee Satisfaction will increase and vice versa. Opinion Eims (2003) sees a delegated leadership style centered on the value of the termination. The word "mission" means a great deal of trust, and a subordinate is required to be the right and right representative.

Variable competence also showed a direct and significant positive impact on Job Satisfaction. If this variable is applied in the Governor's Office of South Sulawesi Province Sub Division of National Unity and Politics of Competence then Satisfaction of Employee will increase and vice versa.

The results of this study also show that Job Satisfaction on Employee Performance has a direct and positive significant effect. So if the variable of job satisfaction is good then the performance of employees will increase, and vice versa if it decreases then automatically Employee Performance will decrease.

In general, the results of the study indicate that there is an indirect influence of democratic leadership, delegated leadership, and competence on employee performance, but directly affect the work satisfaction. This is because the performance of employees is strongly influenced by employee job satisfaction. The higher the job satisfaction the employee performance will be high. Conversely, if employee job satisfaction is low then employee performance is also low. Democratic leadership does not necessarily affect the performance of employees because Democratic leaders in the decision-making process take a long time and difficult to reach an agreement, while employees always want to complete the task quickly, so that job satisfaction decreased employee performance and ultimately not maximal. While delegated leaders do not necessarily affect employee performance, because delegated leaders overly depend on the ability of their subordinates, while low-ability employees cannot perform well. Competence does not necessarily affect the performance of employees because government employees are not applying a high competence, employees are only required to complete the task and job well, and so that competence does not directly affect the performance of employees. The relationship between competence and employee performance is more appropriately called "management myth" and it is difficult to determine which causal link between the two (Robbins \& Judge, 2009). Research shows that organizations with more satisfied employees tend to be more effective than organizations with less satisfied employees. 


\section{CONCLUSIONS AND RECOMMENDATIONS}

The direct relationship between the styles of Democratic Leadership towards Job Satisfaction is direct and significant. The direct relationship of Delegated Leadership style to Job Satisfaction is positive and significant. The direct correlation of Competence style to Job Satisfaction is positive and significant. The results showed that Job Satisfaction on Employee Performance has a direct and significant effect.

The results show that there is an indirect influence between democratic leadership, delegated leadership, and competence on employee performance, but through work satisfaction. It is recommended that in government agencies at the Governor Office of South Sulawesi Province Sub Division of National Unity and Politics use a democratic leadership style to increase job satisfaction for the employees so that the performance of employees will increase. Delegated leadership style is to increase job satisfaction for employees, so that employee performance will increase. Increase employee competence so as to increase job satisfaction for employees, and employee performance will increase. Increase in employee's job satisfaction by using democratic leadership style or delegated leadership style and improve employee competence for employee performance will increase.

This study proves that organizations that have more satisfied employees tend to be more effective than organizations that have less satisfied employees. 


\section{References}

Alam. (2016). Pengaruh Kompetensi Terhadap Kepuasan Kerja Pegawai pada Kantor Dinas Kebudayaan dan Pariwisata Kabupaten Maros. Jurnal...

Arikunto S. (2002). Metodologi Penelitian. Penerbit PT. Rineka Cipta. Jakarta.

Bakrie. (2002). Gaya kepemimpinan dan Motivasi Kerja Pegawai Terhadap Kinerja Pegawai pada Sekertariat Daerah Kabupaten Maros. Jurnal...

Eims L. (2003). Ciri Kepemimpinan yang Efektif. Yayasan Kalam Hidup. Bandung.

Donald. (2007). Human Resource Management. edisi kesembilan. Penerbit : Indeks, Jakarta

Firdaus. (2015), Pengaruh Kepuasan Kerja Pegawai dan Kompetensi Terhadap Kinerja Pegawai pada PT Bandaraya Motor di Makassar. Jurnal...

Gunawan. (2012). Gaya kepemimpinan Demokratik dan Motivasi Kerja Terhadap Kepuasan Kerja Pegawai pada Sekertariat Daerah Kabupaten pangkep". Jurnal.....

Hersey, P. and Blanchard, K.H. (1969). Management of Organizational Behaviour - Utilizing Human Resources. New Jersey/Prentice Hall.

Muslimah. (2014). Pengaruh Gaya kepemimpinan Deligatif dan Kompensasi Terhadap Kinerja Karyawan pada PT Indofood Sukses Makmur Tbk di Makassar. Jurnal...

Noe, AR,T, dkk. (2004). Human Resource Management, 5th edition, Mc Graw Hill, New York.

Reza. (2010). Pengaruh Gaya Kepemimpinan, Motivasi Dan Disiplin Kerja Terhadap Kinerja Karyawan PT Sinar Santosa. Jurnal...

Raymon A.N. et al. (2004). Human Resource Management, 5th edition. MC Graw Hill, New York 2004.

Robbins, S.P., \& T.A., Judge. (2009). Organizational Behavior, Pearson Prentice Hall, United State Of America, New York, hal. 113, 121 dan 128

Sugiyono. (2008). Metode Penelitian Kuantitatif Kualitatif dan R\&D. Bandung Alfabeta.

Sugiyono. (2016). Metode Penelitian Kunatitatif Kualitatif dan R\&D. Bandung Alfabeta.

Siregar S. (2014). Statistik parametik untuk penelitian kuantitatif. Jakarta:Bumi Aksara

Sedarmayanti. (2006). Sumber Daya Manusia dan Produktivitas Kerja. Mandar Maju. 


\section{Bandung.}

Thoha M. (2001). Kepemimpinan Dalam Manejemen. Jakarta: Raja Grafindo Persad

Thoha M. (2006). Kepemimpinan Dalam Manajemen Suatu Pendekatan Prilaku. Raja Grafindo Persada, Jakarta.

Widyatmini. (2008), Hubungan Kepemimpinan, Kompensasi Dan Kompetensi Terhadap Kinerja Pegawai Dinas Kesehatan Kota Depok. Jurnal... 